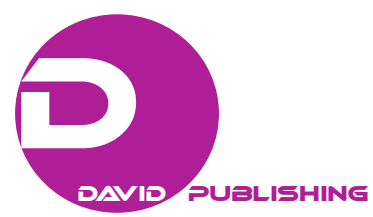

\title{
The City Cenotaph in Southern Saskatchewan: Monuments of “Great Simplicity of Design”
}

\author{
Lloyd Bennett \\ Thompson Rivers University, Kamloops, Canada
}

The First World War did more to disrupt lives and reshape Canadian communities than any event in the short history of that country. Out on the prairies, cities and towns sent volunteer citizens to fight for Canada and the British Empire with memorable success in the Great War. By the 1920s, the communities of Saskatchewan looked to mark the achievements of their soldiers overseas, who did not come home, with war memorials. These cenotaphs or "empty tombs" developed from Boer War models and London's Whitehall cenotaph completed for Armistice Day, 1920. The projects varied from simple cement plinths produced by prairie, stone workshops to the architect-commissioned memorial at Victoria Park, Regina. By the second half of the decade, cities from Saskatoon to Estevan, and towns soon to become cities, decorated their parks and streets with monuments that would become a focus of their community life and remembrance ceremonies for years to come. This paper will document those aspects of the city cenotaph in southern Saskatchewan in terms of community support, site and form selection and aspects of maintenance and the ongoing problem of vandalism, which frustrates city officials and Legion societies to this day.

Keywords: cenotaph, Saskatchewan, Canada, war memorials, British Empire

Remembering the War Dead after 100 Years
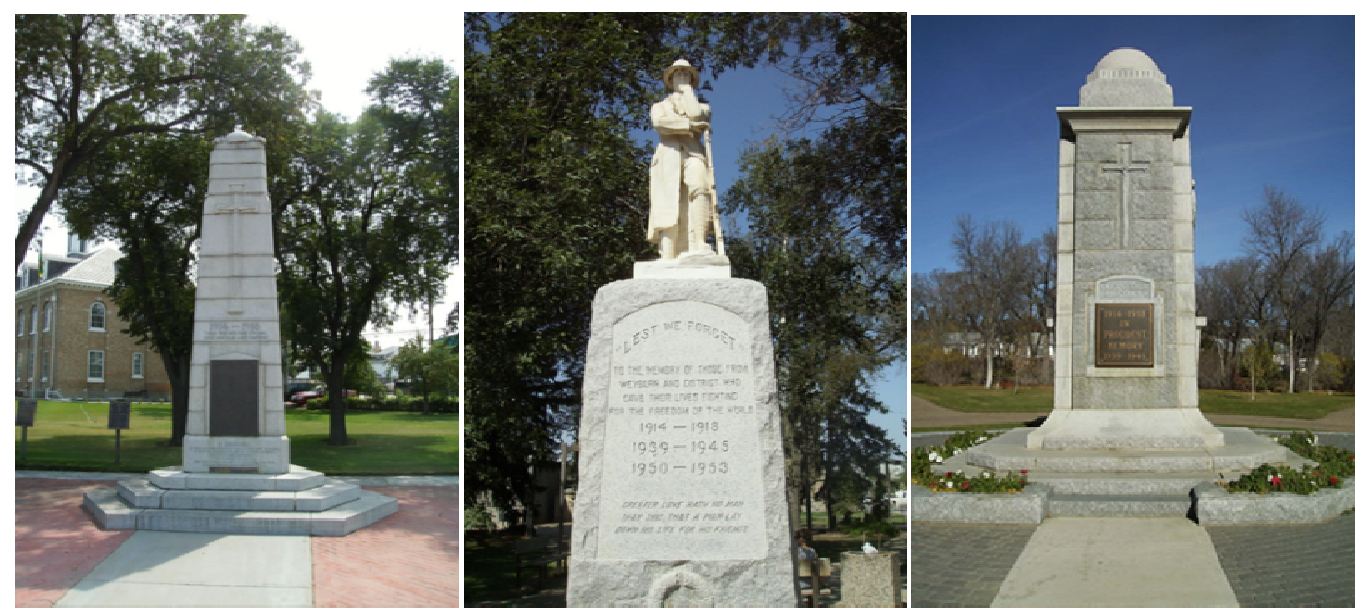

Lloyd Bennett, Ph.D., Art Historian/Associate Professor, Thompson Rivers University. 

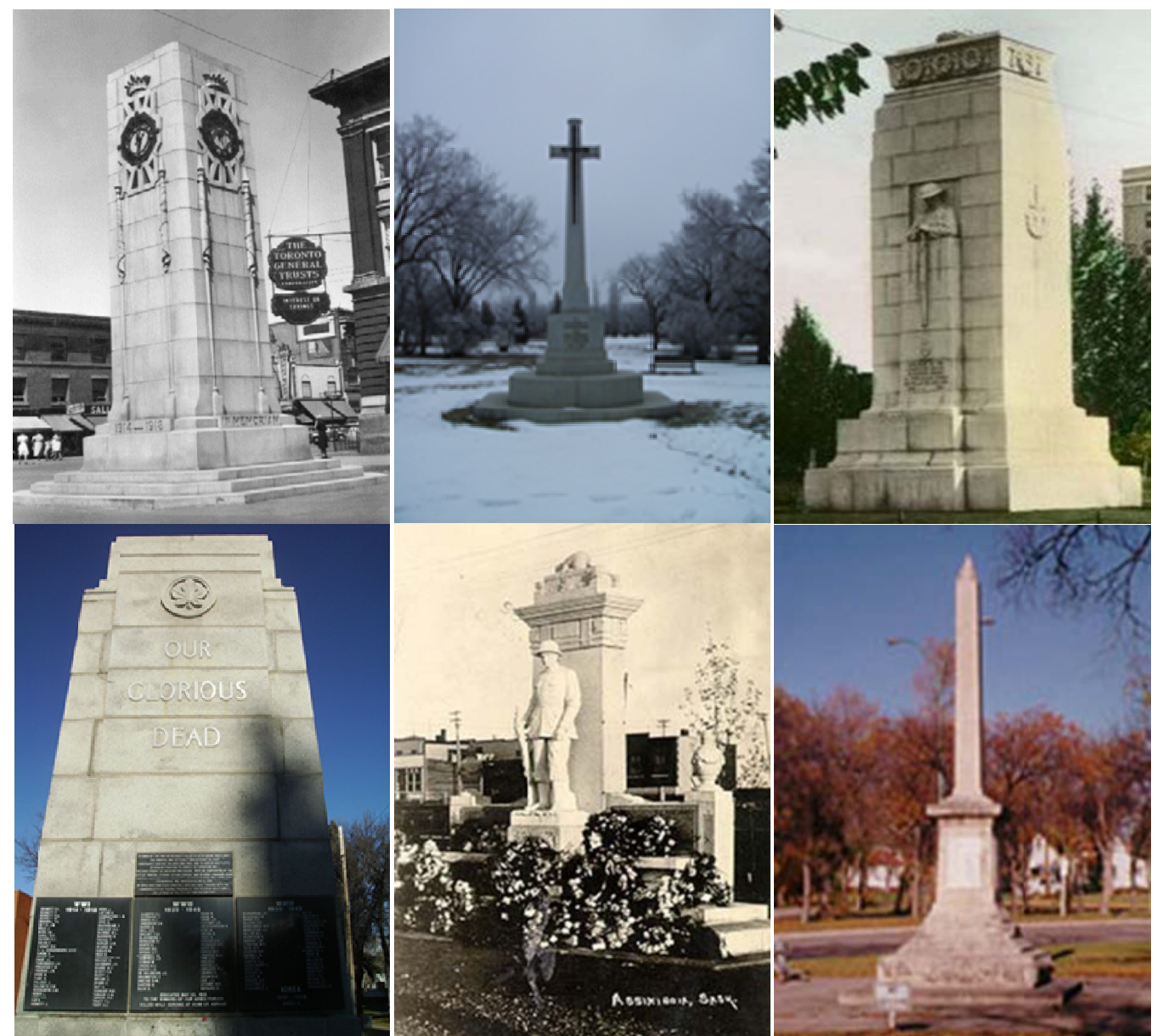

"And some there be, which have no memorial... and are become as though they had never been born... But these were merciful men, whose righteousness hath not been forgotten...Their seed shall remain for ever, and their glory shall not be blotted out. Their bodies are buried in peace; but their name liveth for evermore.” (Ecclesiasticus, 44:9)

As a baby boomer growing up in Moose Jaw, I remember only one public monument that crossed my path, or really stood in my path, as I moved through the city's midtown Crescent Park. This was the impressive cenotaph opened to the public officially at 3:45 pm, 11 November 1923. It received its park setting after alternate sites were rejected, such as the intersection of Main and High Street as being too busy with the city's traffic to accommodate proper reflection on the war dead. ${ }^{1}$ Having grown up, and like so many boomers who moved out of the province to initiate careers, I have had a chance to return and consider the monument again with the advantage of maturity. It is an odd thing that while history does not change, one's appreciation of it reveals itself with age and experience. Now when I sit on one of the viewing benches at the foot of the "Cross of Sacrifice”, instead of rushing by in pursuit of the path to the Natatorium (indoor swimming pool), I am able to reflect on how this city, and the many towns and cities in southern Saskatchewan, made their first public monument initiating a sense of community in remembrance. The monuments, constructed through local fund raising efforts, enhance and add beauty to the prairie cities as one Moose Jaw journalist phrased it, by their

\footnotetext{
${ }^{1}$ Leith Knight, “Council fretted over cenotaph site”, Moose Jaw Times-Herald, 16 August 2009.
} 
"great simplicity of design". 2

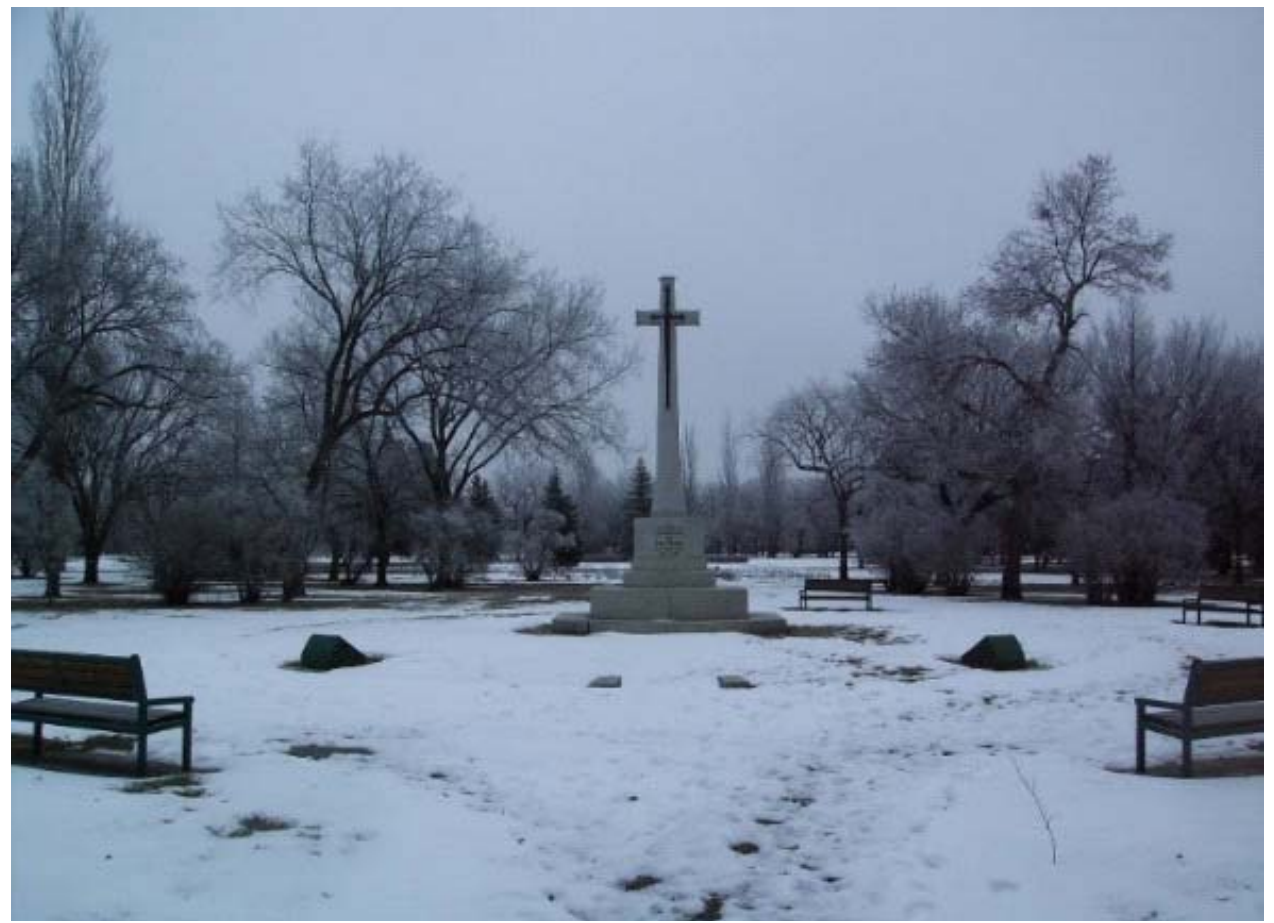

Figure 1. Crescent Park Cenotaph, Moose Jaw, 2014, author’s photo.

\section{Selecting the Site}

The Moose Jaw cenotaph was not at first earmarked for the city's central park as its designer G. Champion called for the High Street location. The designer thought the memorial should be visible "at any season of the year and by the greatest number of people each day." The intersection of the streets further offered an opportunity for citizens to be reminded of the "symbol of Christianity and civilization". ${ }^{3}$ Having considered the Main and High Street location, city council opted to go for the park setting as it would not endanger reflective citizens gazing at the cenotaph amid busy streets. Further, the Crescent Park site would allow for quiet reflection amongst popular trees (planted 1907) and would be able to accommodate large gatherings for remembrance ceremonies.

\footnotetext{
2 "Ceremony at the cenotaph to be most imposing", Moose Jaw Evening News, 25 June 1920. Before the unveiling of the cenotaph in 1923, a temporary nine foot cross, painted white, was erected and reported in the Moose Jaw Evening Times, 15 December 1921. City Council voted to remove the temporary cenotaph on 28 February 1921. Moose Jaw City Council minutes 28 February 1921.

3 As quoted by Knight.
} 

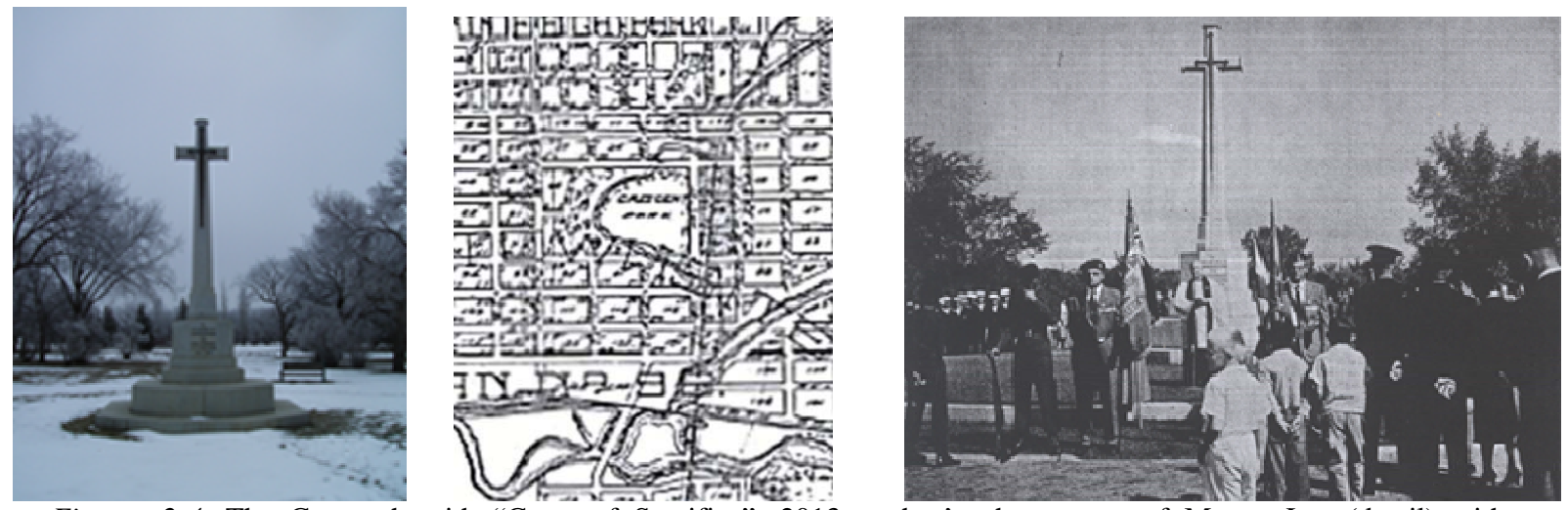

Figures 2-4. The Cenotaph with "Cross of Sacrifice”, 2013, author's photo; map of Moose Jaw (detail) with subdivisions and Crescent Park (centre) east of Main St. (Moose Jaw Library Archives); 1976 memorial service, printed in The Royal Canadian Legion, Golden Years 1926-1976, Saskatchewan Branch No. 59, Moose Jaw, SK.

As with the Moose Jaw plan, the prairie cenotaph was marked by the strict geometry determined by the grid layout of the early settlement. They were placed in spaces not occupied by buildings and thusly tend to follow a square or rectangle ground plan in the urban setting. The cenotaph can mark the focus of a park with approach paths or avenues from the sides, as at the Victoria Park layout in Regina, or, create a sculptural accent on a busy street as at Saskatoon with the clock cenotaph at 21st street (since moved to City Hall Square). At Weyburn and Estevan, the memorial was presented off a street corner becoming a downtown sculptural accent. Yorkton carried out the idea of a grand approach to their cenotaph with a flower lined boulevard on Darlington Street. The intersection of the street at Second Avenue North, below the city court house, gave the memorial a setting for a processional way as the practice in overseas cities. By 1919 a committee was formed to work on the Yorkton War Memorial project where they discussed issue of the site:

Land: There had been talk that the memorial site should be on Broadway, but it was decided to erect an impressive monument at the intersection of Second Avenue and Darlington Street. The Town of Yorkton undertook to donate the site and develop it. The cost of preparing the land for the monument, building the boulevard, which included widening Darlington Street between First and Third Avenue was borne by the Town of Yorkton at a cost of approximately \$12,000. This work was done in 1929, one year after Yorkton achieved city status. ${ }^{4}$

The cenotaph was commissioned to Hooper Marble Works of Winnipeg who carried out the design in granite with maple leafs in roundels above bold lettering of "Our Glorious Dead". There is no evidence that the Yorkton town council provided exact details as to form of the cenotaph but likely accepted a design from the Winnipeg Company, which proposed various options for memorials from the mass of granite block at Yorkton to the cement obelisk ${ }^{5}$ type built at Kamsack, Saskatchewan, 1920. As the Saskatchewan cities were essentially devoid of public sculpture, the war cenotaph introduced a visual reference in the centre of the community.

After the First World War, London became a focus for post-war remembrance with their cenotaph at Whitehall. This temporary memorial would become permanent and provide a model for the "empty tomb", but the form the design would take in smaller centres of the Commonwealth would be based upon post-war budgets

\footnotetext{
4 Terri Lefebvre Prince, History Corner, Yorkton This Week, 19 May 2010.

${ }^{5}$ National Inventory of Canadian Military Memorials (NICMM), veterans.gc.ca. The obelisk was a popular design for First World War memorials in western Canada. The Veterans Affairs database records 86 memorials of the obelisk type for the four western provinces. The Anglo-Boer War Memorials Project (ABWMP) lists 23 memorials of the obelisk type. See www.casus-belli.co.uk/abwmp (15 December 2015).
} 
and the plans provided by architectural firms and the stone workers' companies, which often revealed an eclectic taste of designs from antique motifs to the Cristian crucifix.

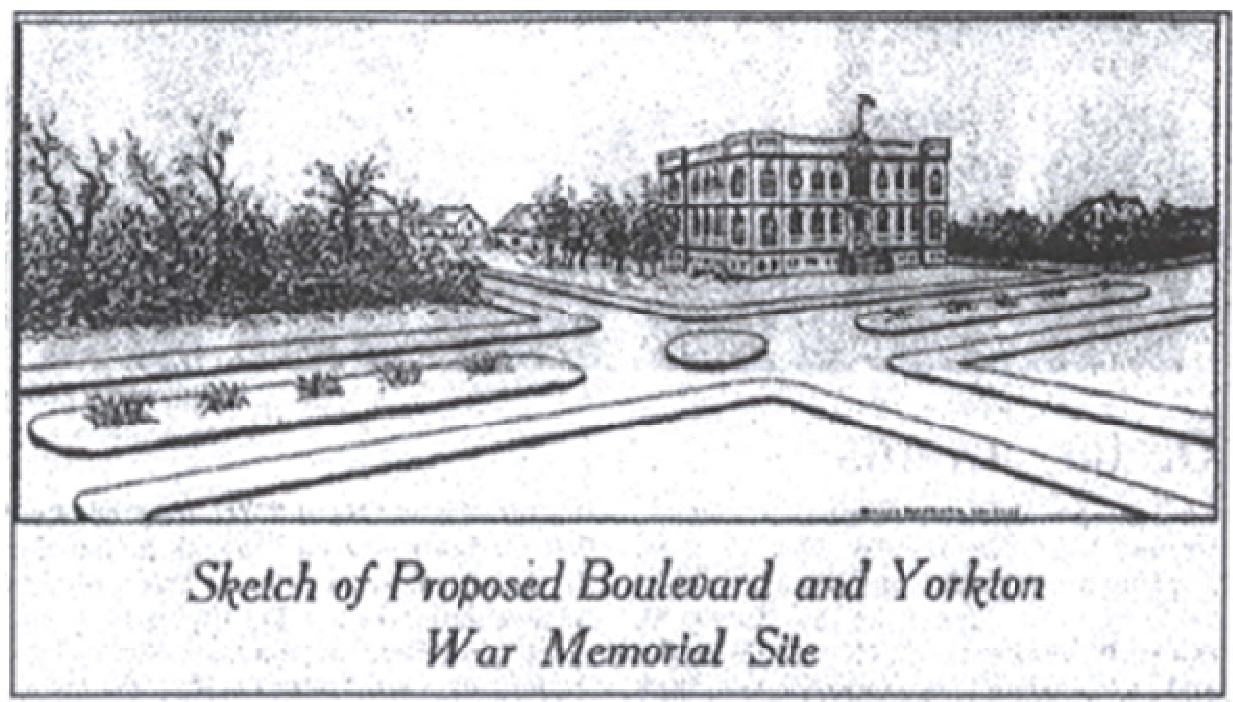

Figure 5. City of Yorkton Archives, Yorkton, Saskatchewan.

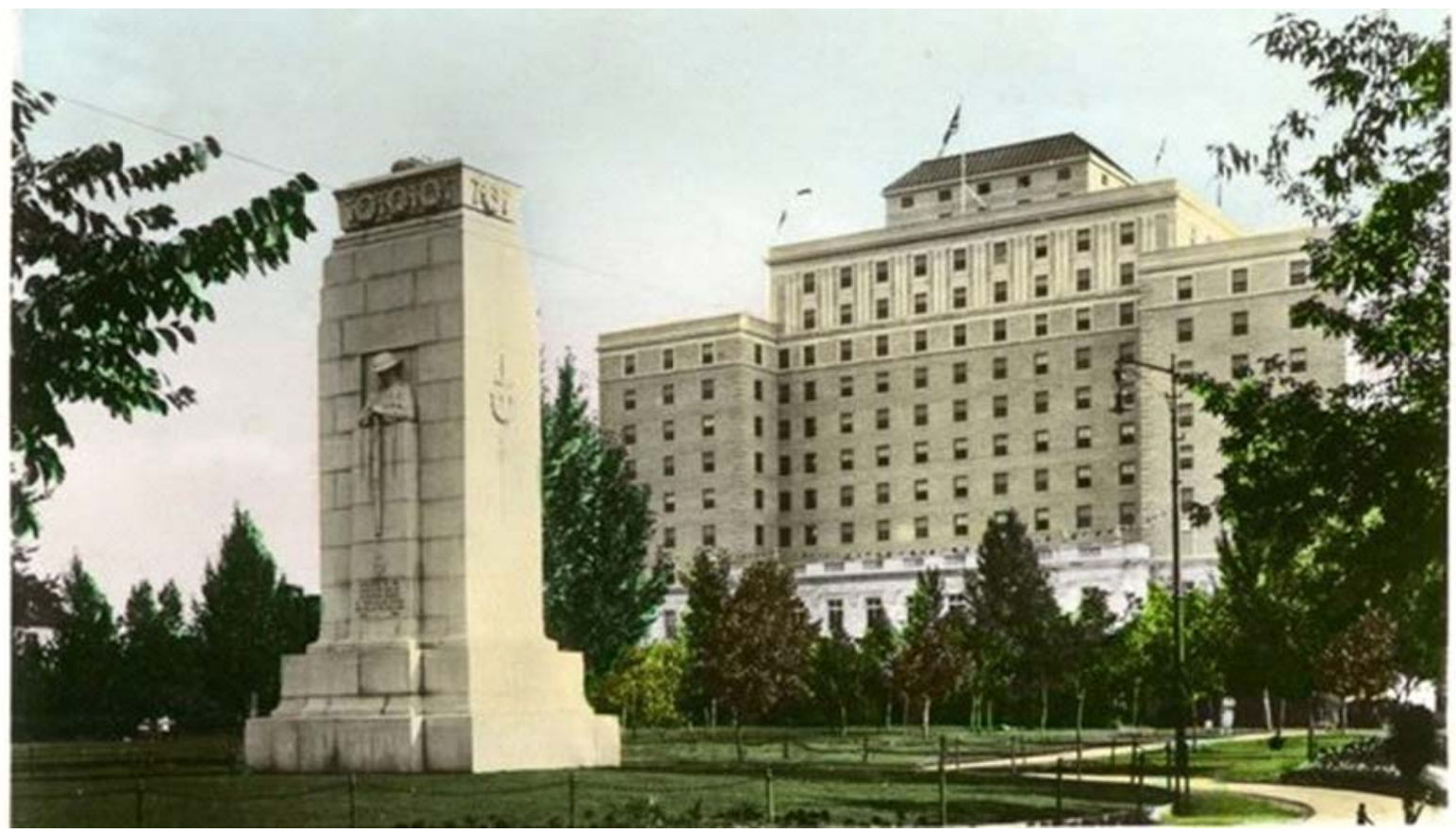

Figure 6. The Cenotaph, Regina, Victoria Park, Postcard Collection, LXX-415, University of Saskatchewan Archives. 


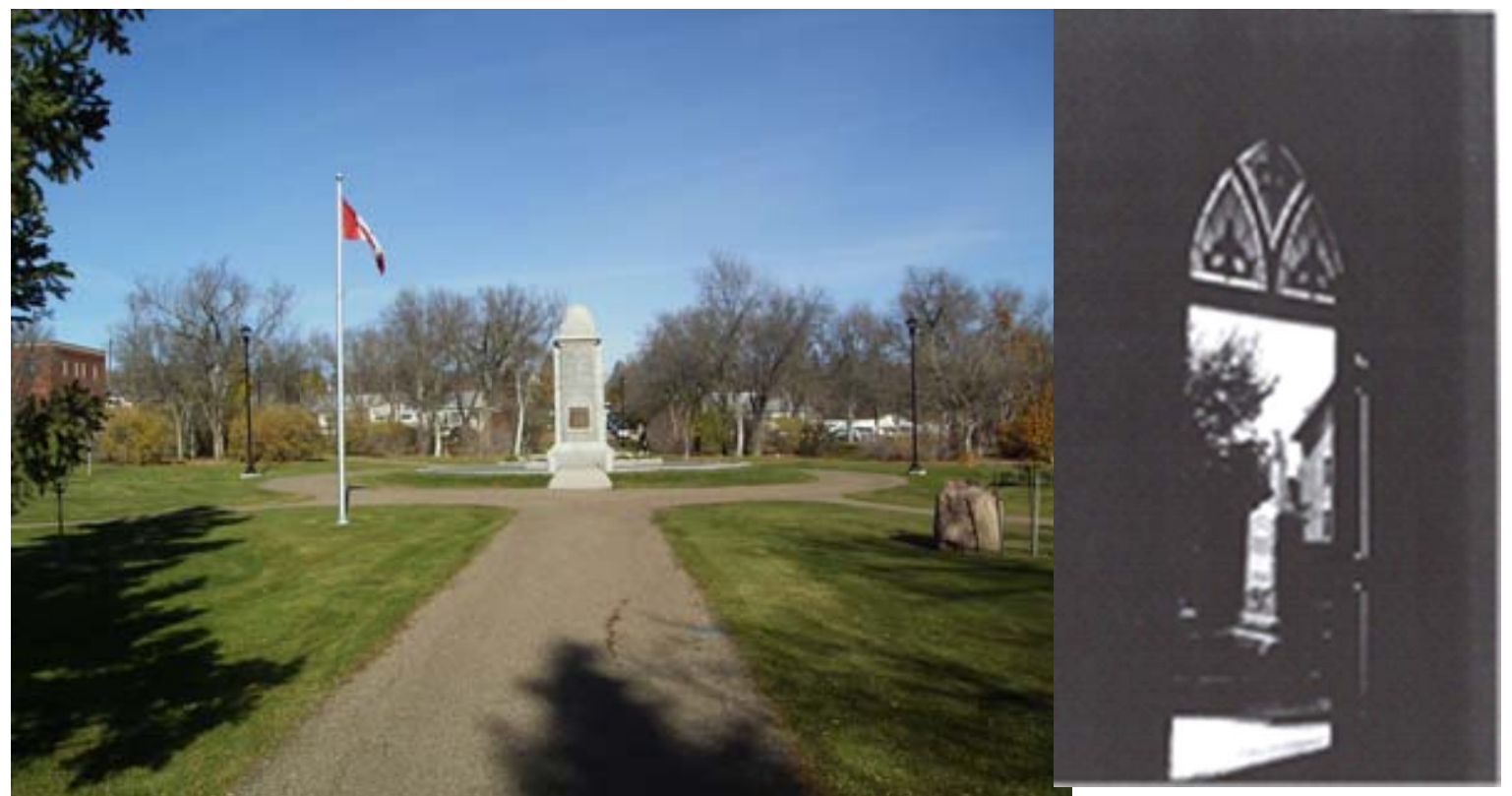

Figures 7-8. Swift Current's parkland cenotaph at Memorial Park, author's photo; Weyburn street War Memorial as seen from inside Grace United Church, 002.001.202, Soo Line Historical Society Inc.

\section{Setting the Form}

An important influence on the prairie cenotaph can be traced back to the 1915 concern of the Imperial War Office to account for war dead. Fabian Ware, touring the Front for the British Red Cross, petitioned the government to name an "official agency" to look after war dead and the Graves Registration Commission was created and by February 1916 this organization became the Directorate of Graves Registration and Enquiries. A wider body for the care of graves emerged in May 1917 and was termed the Imperial War Graves Commission headed by the Prince of Wales. A principle concern of the graves commission was to design cemeteries for the overseas dead.

Ware invited architects Edwin Lutyens, Herbert Baker and Charles Aitken to visit cemeteries near the Front "to formulate broad ideas for the post-war design of these burial grounds":

The group met formally on 14 July after the trip ended. Ware, Lutyens, and Baker agreed that every cemetery ought to obey a general theme...that there should only be variations on the theme (monumental, garden or woodland, village, and town cemeteries), that grave markers should be uniform headstones (not crosses), and that cemetery walls should be horizontal...Baker wanted a cross at each cemetery, but Lutyens wanted a more abstract symbol. ${ }^{6}$

Trial cemeteries in France where the concept of uniform grave stones surrounded by a low wall initiated the plan of what would be the Imperial War Graves Commission graveyard. These sights were made peaceful with the planting of trees, shrubs and flowers. The commission came up with two standard memorials, Lutyens "Stone of Remembrance" and the "Cross of Sacrifice” designed by Reginald Bloomfield. The cross was used at many overseas cemeteries and was often used in cenotaphs as at the Moose Jaw Crescent Park location.

The official, British First World War cenotaph would come from Lutyens' temporary wood and plaster design put up in Whitehall to mark the end of the war in London. The architect envisaged a tall plinth rising in

\footnotetext{
${ }^{6}$ Wikipedia, “Development of the war cemetery ideal” (29 December 2015).
} 
levels to a lidded sarcophagus with a pyre and the sides to be ornamented with stone flags and laurel wreaths. The permanent flags did not become a part of the monument but these spaces became occupied with real flags. Drawings by Lutyens from 19th July 1919 Peace Day events (today in the London Imperial War Museum, Figure 9) reveal that the Royal Academy member took into account the massive Whitehall buildings for the setting. As with the first parade in 1919, the procession would pass by the cenotaph as the focus of remembrance celebrations for years to come filling the raised base with coloured wreaths. Details of the commission reveal Lutyens used antique reference points for his design:

The final design was based on measurements of the Parthenon. In the classical manner, all the surfaces were subtly curved; the verticals would meet at a point 1000 feet above the ground and the horizontals, 900 feet to the side. Stripped of all literal elements (at Lutyens' insistence four soldiers at the base were not included), the simplicity and dignity of the monument became the immediate focus for national grief. The wood and plaster structure was unveiled on 18th July and was originally intended to stand for a week. Its extraordinary popularity extended this to January 1920 when the weather finally forced its removal. In the meantime, a slightly revised design was accepted by the Cabinet for a permanent memorial, again sited in Whitehall and unveiled on Armistice Day, 1920. The Cenotaph remains the central focus of remembrance. $^{7}$
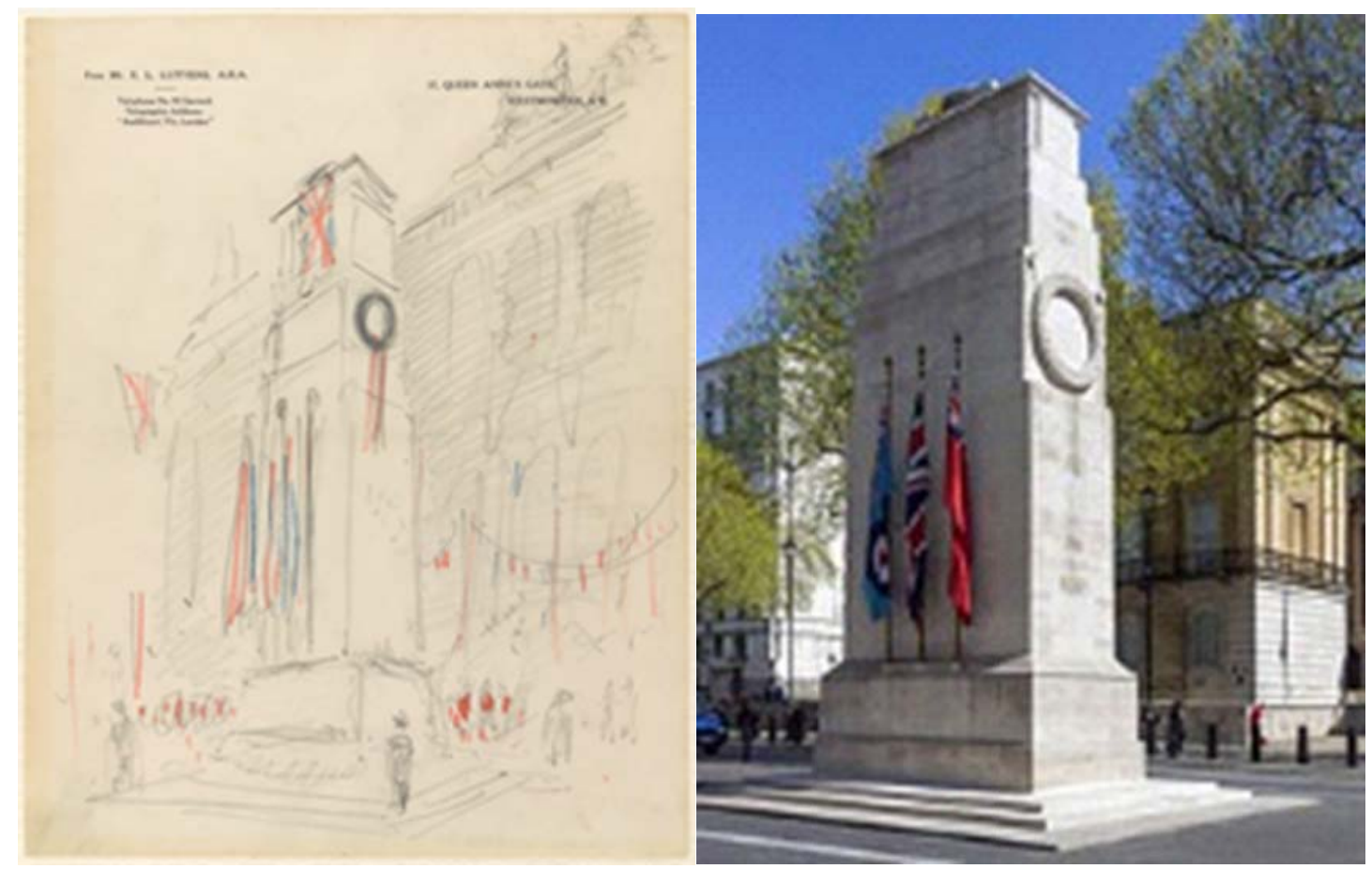

Figures 9-10. Edwin Lutyens, Study for the Cenotaph, a sketch of the proposed cenotaph "in situ” with coloured flags, 1919, Art. IWM ART 163771 1, Imperial War Museum, London; Whitehall Cenotaph today, London.

While Lutyens' model was grand to meet the demands of its position at Whitehall, rising a thousand feet above the street, it was essentially a horizontal monument emphasizing the empty sarcophagus symbolic of the absentee soldier who died overseas. The design recalled Renaissance tombs (Medici) in its somber elegance of the plinth rising in steps to the dignified tomb. Lutyens use of the classical language carried with it the message of the universal sacrifice of the Great War trumping any reference to class position or sectarian tribute. This

\footnotetext{
${ }^{7}$ Art.IWM ART 16377 1, Study for Cenotaph, label comments, Imperial War Museum, London, iwm.org.uk.
} 
levelling of the memorial message remained fixed with the inscription "To the Glorious Dead" engraved on two sides of the Whitehall cenotaph. ${ }^{8}$ Lutyens' design was well received and became approved for permanent display to be carried out in Tyndall limestone at the centre of British government and a model for Commonwealth countries commissioning memorials for their overseas dead. Some cities, such as London, Ontario, made a smaller replica of the Whitehall cenotaph, but more often the Canadian memorials were less ambitious utilizing plinths and obelisks for their cenotaphs.

Looking at the south Saskatchewan city cenotaph (see title page), one can see that the designs shared common features with the Whitehall memorial. All of the monuments have been placed in positions of honor recognizing the significance of those who did not return home from the war. It should be remembered that in the First World War by far the largest number of dead were civilians and it was the people of these towns and cities that brought the widespread demand for post-war memorials. ${ }^{9}$ This position of dignity was further realized by having the monument raised above the street or park to allow the visitor a position of reverence below the monument to reflect upon those who gave the greatest sacrifice. This focus of the citizen remembering the relative, or friend, remained fixed by having names listed on the cenotaph so that the community member does not get lost in the general tribute.

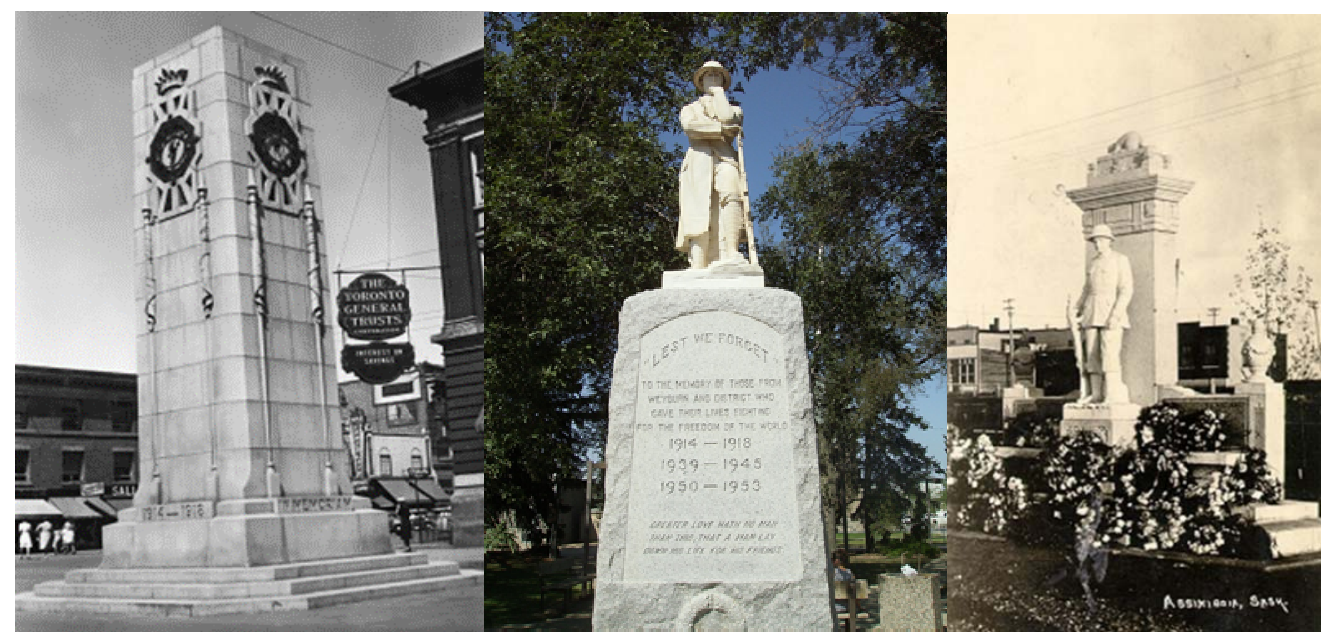

Figures 11-13. Clock cenotaph, Saskatoon, c. 1930s, Glenbow Archives NA-1088-19; Weyburn cenotaph today; Assiniboia cenotaph 1927, Assiniboia Museum archives.

Generally, the Saskatchewan memorials take the form of a shaft or obelisk rather than the broad form of the London cenotaph. The Victoria Park Regina memorial is the closest design to have a structure of sufficient width to hold the sarcophagus decorated with raised wreaths in stone. Most First World War memorials in Canada can be traced back to Commonwealth Boer War designs of crosses, obelisks, plagues, tablets and figures on plinths. ${ }^{10}$ Other motifs reflect national symbols such as the maple leaf (Weyburn) or the beaver (Assiniboia) and British empire designs such as the Union Jack and Crown against a radiant sun with 'Lutyens' permanent flags” (Saskatoon). There are several antique references beyond the sculpted wreaths, as the

\footnotetext{
${ }^{8}$ Lutyens had planned to have free standing sculpture at the base of the cenotaph but this was never carried out in the permanent presentation.

${ }^{9}$ Neil Hanson, The Unknown Soldier: The Story of the Missing of the Great War (Toronto: Doubleday, 2005). The author notes Great Britain erected "fifty to sixty thousand" memorials in stone, p. 402. Veterans Affairs, List of Memorials, Municipalities for the Province of Saskatchewan lists 715 entries. See http://www.veterans.gc.ca.

10 ABWMP, Survey/Types and Form of Memorial (Meurig Jones).
} 
Assiniboia cenotaph have decorative Grecian style urns and finish the central plinth with a triglyph-metope frieze and a cornice. The Assiniboia memorial originally included a standing soldier raised up on a plinth a few feet off the ground but this figure has been removed in the new setting before city hall as the statue was damaged by vandalism. The Weyburn memorial has a wonderful marble statue (carved in Italy) of a soldier standing at ease gazing at the field before him. While this figure was raised above easy access (it would be vandalized) it has avoided the fate of the Assiniboia statue. Another carving that has avoided destruction, if not vandalism to the site, is the impressive "brooding soldier" of the Regina cenotaph. Here the helmeted figure in its protective niche looms thirty feet above the ground rest his arms on the inverted Lee Enfield rifle and seamlessly blends into the tomb memorial. Unlike Boer War memorials, where figures and horses were used in active poses (London, St. James Park; Montreal, Dorchester Square), First World War cenotaphs tend to use single figures of the common soldier that are contemplative eschewing romantic action of the 19th century. By 1918, war lost much of its jingoism, helped by the war poets, who challenged Victorian romance of battle for the realities of the destruction of big guns, flame throwers and poison gas. The mood in Britain and the Commonwealth countries was part of the international call to order in the wake of great destruction, which encouraged reflection made popular by such memorials as the Cross of Sacrifice.

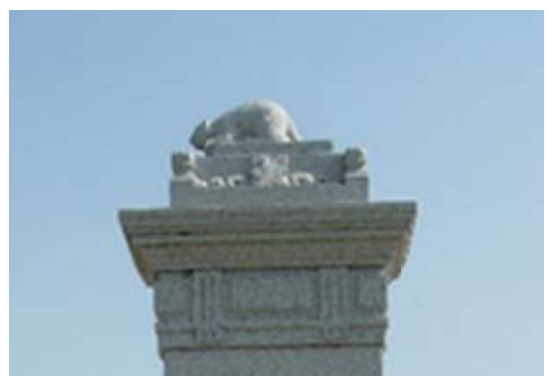

Figure 14. "Beaver" detail of the Assiniboia cenotaph at its current location in front of City Hall, Assiniboia, Saskatchewan, author's photo.

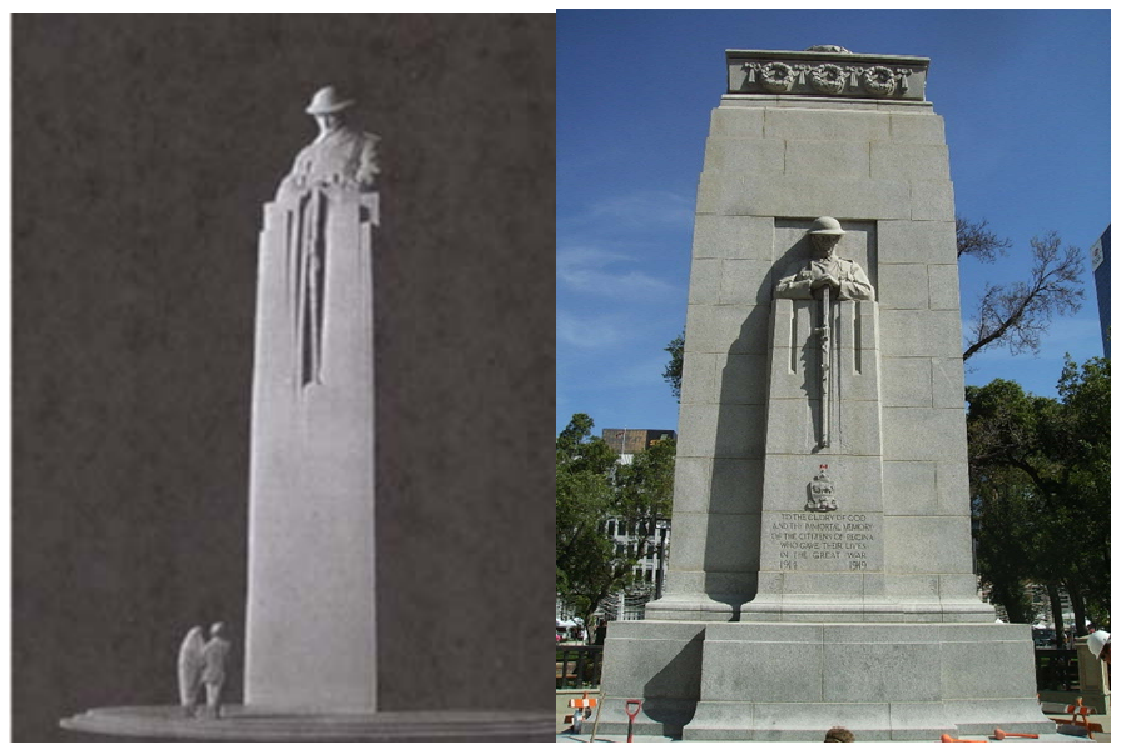

Figures 15-16. Model of cenotaph to be placed in Victoria Park, Regina, 1921. Designed by F. Chapman Clemensha, in Saskatchewan Archives Board scrapbook album R-1392, p. 55; Victoria Park cenotaph, author’s photo. 

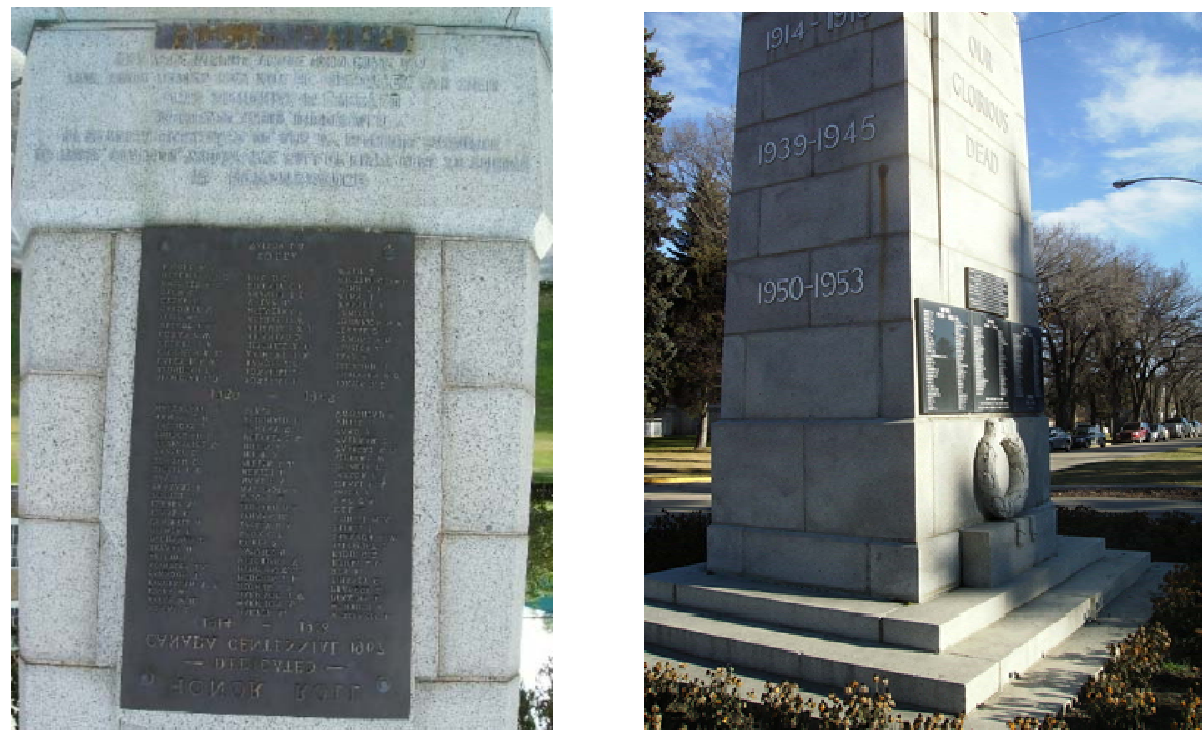

Figures 17-18. Cenotaph name plates at Estevan and Yorkton, author’s photos.

\section{Cross of Sacrifice}

The war memorial that became the most consistent and popular design was Reginald Bloomfield's "Cross of Sacrifice”. Fabian Ware has been quoted as indicating that it was not known how the name appeared but the memorial was featured to mark orientation in cemeteries, "nearly one thousand"11 in France and Flanders (in cemeteries with over 40 graves). "The cross is there to show the religion of most of the dead, which was Christianity. The sword shows that the cemetery is to do with war."12 The design would be repeated around the world to mark reverence to those who died in world wars that varied from the colossal (over 12 meters) Halifax cross to the Canadian gift at the Arlington Cemetery to Americans who died with Canadian forces in World War I. The cross was used 25 times in Canadian provinces and appears three times in Saskatchewan at North Battleford, Regina and Moose Jaw. ${ }^{13}$

If the Whitehall cenotaph reappeared in various forms, the copies of the Cross of Sacrifice followed a specific design. The cross was to be made of white stone. In Canada this was usually granite but Portland stone was used in England and limestone in France and Belgium. There were at least four heights to the cross: " 14 , 18, 20 and 24 feet for different sizes of cemetery". ${ }^{14}$ Precise instructions outlined the making of the cross:

\footnotetext{
11 David Crane, Empires of the Dead: How One Man's Vision Lead to the Creation of WWI's War Graves (London: William Collins, 2013), p. 172.

12 “About the Commonwealth War Graves Commission cemeteries and memorials”, cwgc.org (29 December 2015).

13 National Inventory of Canadian Military Memorials (NICMM), veterans.gc.ca. Memorials using the Cross of Sacrifice by province: British Columbia: Esquimalt Veterans Cemetery (59005-007), Duncan Charles Hoey Memorial Park (59012-007), Salmon Arm (59014-009), Vancouver Mountain View Cemetery (59029-003), Victoria Ross Bay Cemetery (59032-014); Alberta: Calgary Burnsland Cemetery (48002-063), Calgary Union Cemetery (48002-064), Medicine Hat Hillside Cemetery (48020-013); Saskatchewan: North Battleford City Cemetery (47001-005), Moose Jaw Crescent Park (47005-002), Regina Cemetery (47007-011); Manitoba: Brandon Veteran’s Cemetery (46001-015), Winnipeg Brookside Cemetery (46009-006); Ontario: Ayr (35011-001), Guelph (35026-008), Hamilton Cemetery (35031-012), Kingston (350036-005), Parkhill Coronation Park (35039-043), Ottawa Beechwood Cemetery (35061-004), Toronto St. Paul's Anglican Church (35090-004); Quebec: Montreal Mont-Royal Cemetery (24045-003), Battlefields Park (24051-054); New Brunswick: Rothesay Common (13009-014), Saint John Cedar Hill Cemetery (13009-014); Nova Scotia: Halifax Point Pleasant Park (12004-136); Newfoundland and Labrador: Gander Cemetery (10003-001).

${ }^{14}$ Jeroen Geurst, Cemeteries of the Great War by Sir Edwin Lutyens (010 Publishers, 2010), p. 46.
} 
The cross consists of three pieces: The shaft, from base to crossarm; the crossarm; and the upper shaft, above the crossarm. The crossarm is fastened to the lower and upper shaft by two bronze dowels. A joggle (a portion of the shaft which extends into the base, acting as a joint) about 6 inches $(15 \mathrm{~cm})$ long extends into the base, where it is secured by another dowel. The shaft and crossarm are both octagonal in shape, and the shaft tapers slightly as it rises to give the cross entasis. $^{15}$

Attached to the cross was a bronze long sword which pointed down following the form of its support.

Bloomfield commented on the intent of his cross: "What I wanted to do in designing this Cross was to make it as abstract and impersonal as I could, to free it from any association of any particular style, and, above all, to keep clear of any sentimentalism of the Gothic. This was a man's war far too terrible for any fripperies, and I hoped to get within range of the infinite in this symbol."16 If the designer wished to avoid association with "any particular style", he clearly built his cross on the model of the Greek temple. The white stones stack up with consummate clarity as any Doric building emphasizing the architectural solidity of the cross. The fact that the design came with precise specifications for its limitation of sizes further makes the monument repeatable as a classical structure. Reproduced in countries all over the world, the Cross of Sacrifice has attained the status of a universal symbol, whether in a national cemetery or a city park in Moose Jaw.

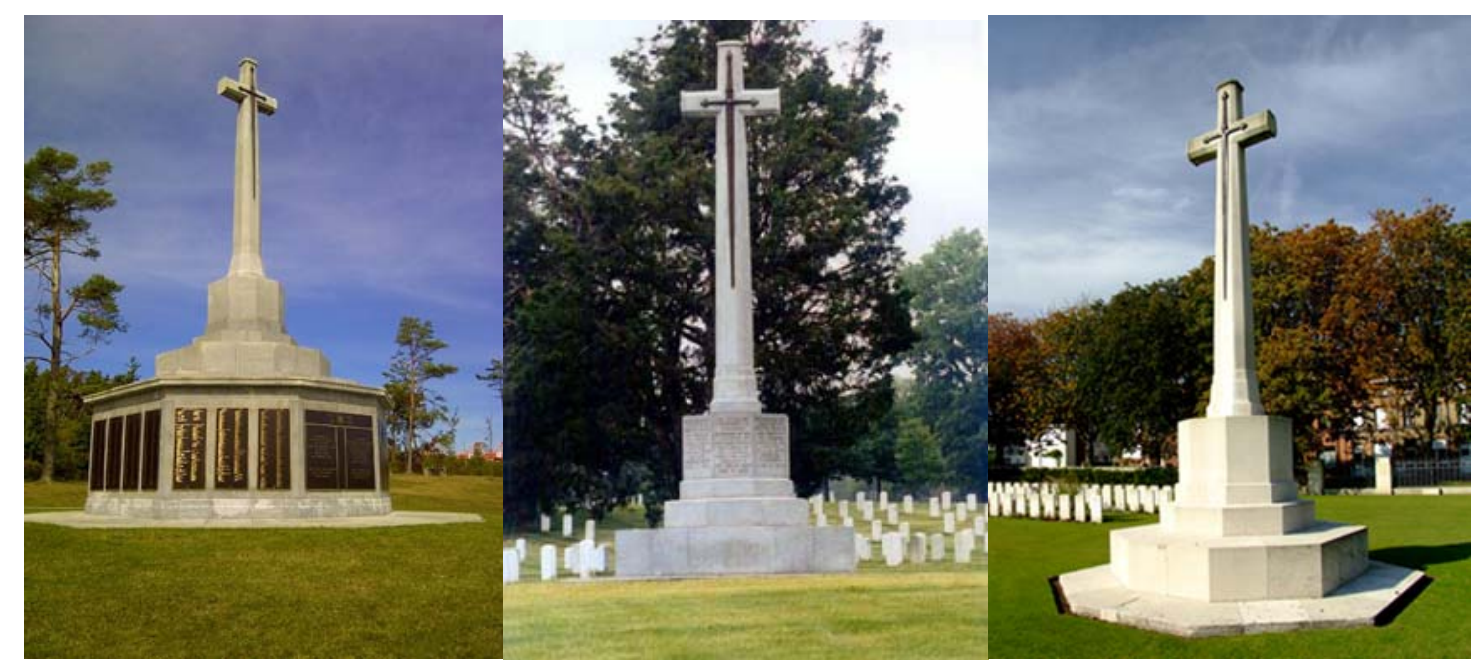

Figures 19-21. The Cross of Sacrifice at Halifax, Arlington Cemetery, Ypres Resevoir Cemetery. Photos wikimedia commoms and veterans.gc.ca/images.

\footnotetext{
15 Fabian Ware, "Building and Decorating of the War Cemeteries”, Journal of the Royal Society of Arts, 1924, 347, reprinted in Wikipedia, “Cenotaph” (31 December 2015).

16 “Rye, Sussex: Home of the Menin Gate Designer”, BBC.co.uk, 30 July 2014 (20 December 2015).
} 


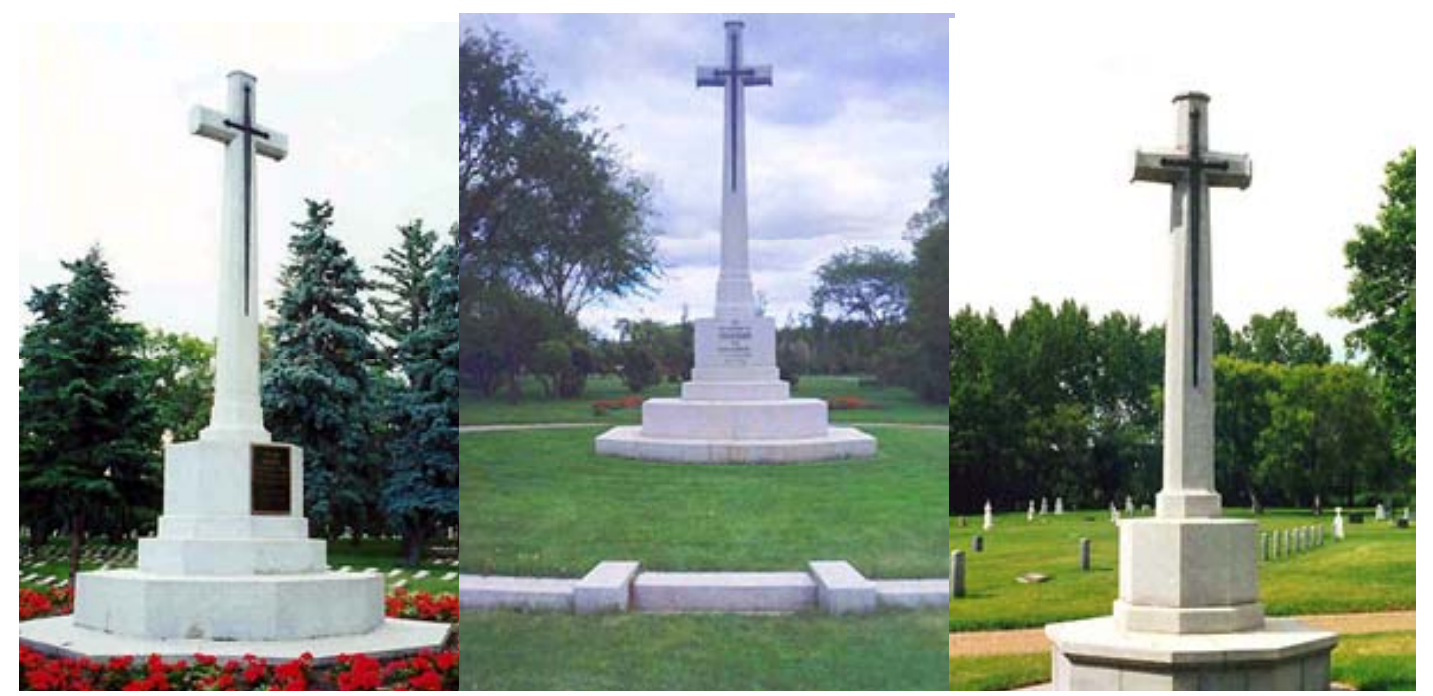

Figures 22-24. Saskatchewan Crosses of Sacrifice at Regina, Moose Jaw and North Battleford. Photos veterans.gc.ca.

The best time to view the Crescent Park cenotaph is in the morning when the soft light reflects off of the faceted faces of the cross. The tall cross faces west as it looms over a circular space of grass. From the eight-sided granite base (meant to simulate shell casings), ${ }^{17}$ the structure rises with a series of steps to a pedestal that elegantly holds the twelve foot cross. The movement from the horizontal base to standing Latin cross is achieved by having the base supports become more vertical until the last section makes a gentle curve upwards to the bottom of the cross. The granite shaft has a slight curve (entasis) giving the form an organic bulge as the vertical member tapers upward. The top of the cross and crossing arms do not just end, but are capped to clarify that this is where the structure ends with these proportions rising to eighteen feet. These characteristics recall the sophisticated design planning of the Greek temple where every part of the structure performs a function for the overall effect of the form.

The placing together a sword with the Christian cross leads to possible interpretations that sought to accommodate those who opposed the war and those who supported it. The long sword suggests the chivalry of the crusades and the fight for Christianity where Christ militant assumes the role of a warrior to save humanity. The biblical referenced would be the passage "turning swords into plowshares”"18 where the war reference has returned to productive life. However, because the cross dominates the sword, the larger idea is that faith in the church governs the military response as it is a temporal interruption against the timeless relevancy of Christ and his followers. Rudyard Kipling's inlayed words (from Ecclesiasticus) ${ }^{19}$ on the pedestal, "Their Name Liveth Forever More" finalize the link between the war dead and their eternity in Christianity. ${ }^{20}$

\footnotetext{
17 “Veterans Cemetery, God’s Acre-The Cross of Sacrifice”, veterans.gc.ca (20 December 2015).

18 Isaiah 2:4: "And He will judge between the nations, and will render decisions for many peoples; And they will hammer their swords into plowshares and their spears into pruning hooks. Nation will not lift up sword against nation, and never again will they learn war.” Biblehub.com (20 December 2015).

19 Ecclesiasticus, 44:9: And some there be, which have no memorial....and are become as though they had never been born...But these were merciful men, whose righteousness hath not been forgotten...Their seed shall remain for ever, and their glory shall not be blotted out. Their bodies are buried in peace; but their name liveth for evermore.

20 The pedestal inscriptions are: [west face] TO THE MEMORY OF THOSE WHO DIED FOR KING AND COUNTRY IN THE GREAT WAR 1914-1919; [north face] SOUTH AFRICAN WAR 1899-1902; [east face] THEIR NAME LIVETH FOREVERMORE [south face] SECOND GREAT WAR 1939-1945 KOREAN WAR 1950-1953.
} 


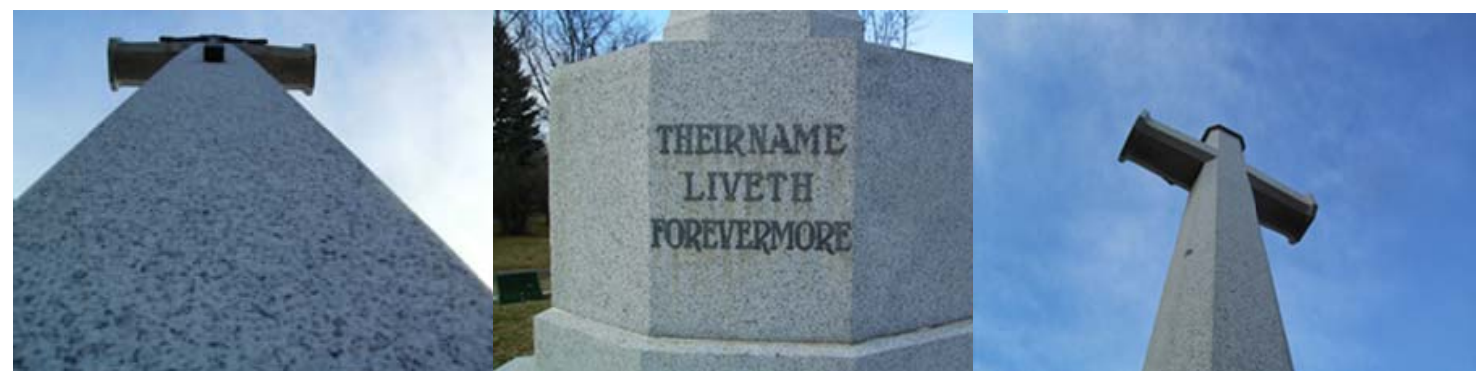

Figures 25-27. Views of the Moose Jaw Crescent Park cenotaph, author's photos.

The origin of the Cross of Sacrifice was to present a Christian symbol in the Commonwealth cemeteries of France and Flanders, as the graves would not be marked with crosses; the practice of placing the Cross of Sacrifice in cemeteries was largely followed in Canada (see note 13), as in Saskatchewan at North Battleford and Regina. Moose Jaw, however, had a history of community that linked charity organizations, government and the church and therefore selected a civic space for their city war memorial that paid tribute to the cross of Christ. An example of the city's non separation of church and state, occurred in February 1923 when the Imperial Order of the Daughters of the Empire unveiled their gift of war art reproductions (IODE Proofs); they displayed the pictures in St. Andrews Church at the provincial School Trustees Convention where premier Charles Dunning (Moose Jaw County) was invited to speak on the merits of Saskatchewan. There was no sentiment that thought a "martial spirit" was being promoted by having war pictures in a Christian church, nor did any school trustees speak up against a charity organization influencing images the public school children might see. ${ }^{21}$ Moose Jaw remained a united community and the citizens' war memorial would combine church service with Remembrance Day activities. As the premier of the province put it in his 1923 "Saskatchewan" speech, he credited Moose Jaw for its pioneers and the "neighborliness" of its Presbyterian church. ${ }^{22}$

\footnotetext{
${ }^{21}$ When the IODE offered their pictures in Burnaby at a P.-T. A. meeting, a lady "raised a storm of protest" against hanging the pictures in the schools as they "glorified war" and would imbue the children with a "martial spirit". See "Disapprove of war Pictures for School Decoration”, Vancouver Sun, 17 March 1923. When the war pictures arrived in Calgary in October 1926, one school board member claimed the "pictures glorified war and the heroism of war". See "War Pictures Not Horrible: Very Common”, Calgary Albertan, 9 October 1926.

22 “Dunning tells the School Trustees”, Moose Jaw Evening Times, 22 February 1923.
} 


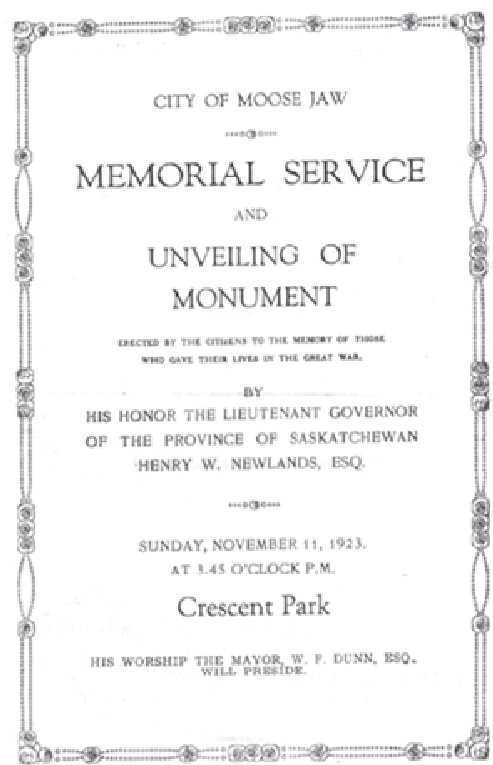

Figure 28. Cover of Moose Jaw cenotaph memorial service and unveiling program.

\section{Community Support}

Remembering the dead of Saskatchewan's cities and towns after the Great War set the precedent for public memorials that continued to be supported until this day. Mark Sheftall makes the point that Commonwealth countries saw the Great War as a "rite of passage" where a conservative approach to memorials would assist in promoting the new nations. ${ }^{23}$ This would account for the many Canadian memorials that derived from Boer War designs and the popularity of the Cross of Sacrifice, which combined established traditions of religion and war. Saskatchewan communities were eager to remember their dead in the manner of public display with memorials and remembrance services. Even if city councils had to raise money through subscription sales in the town cenotaph, the task was eventually completed.

Moose Jaw put up a nine foot temporary cross in their central city park, supplied by the United Services Club, until funds could be raised for the unveiling of their permanent Cross of Sacrifice in 1929. ${ }^{24}$ Two years earlier the Lieutenant-Governor H. W. Newlands unveiled the memorial at Swift Current, much to the pride, and promise of maintenance, of the city and "surrounding community", who raised the $\$ 10,000$ for their cenotaph. ${ }^{25}$ In Regina a competition was announced in 1925 for a cenotaph, which was won by the Montreal firm of Ross and Macdonald and aided by Regina architect F. H. Portnall; ${ }^{26}$ the project, its image later used on provincial license plates (Figure 29), would become the centre piece for war remembrance in the province. At Yorkton, \$25,000 was estimated to cover the expenses for the proposed memorial that called for a granite monument with the names of "notable battles" and "those who died in service" with "a bronze statue of a Canadian Infantryman”. ${ }^{27}$ Beyond community and area fund raising, the memorial committee targeted local

\footnotetext{
${ }^{23}$ Mark Sheftall, Altered Memories of the Great War: Divergent Narratives of Britain, Australia, New Zealand and Canada (London: I. B. Tauris \& Co. 2009), p. 145.

24 "Memorial Cross is almost ready", Moose Jaw Evening Times, 15 December 1921.

${ }^{25}$ Golden Furrows: An Historical Chronicle of Swift Current (Swift Current: Local Council of Women, 1954$)$, p. 31.

26 William Argan, Regina: The First Hundred Years (Regina: The Leader-Post Carrier Foundation Inc., 2002), p. 63.

27 Yorkton War Memorial Committee, Resolution of the Committee concerning the raising of funds and the erection of a War Memorial in the Town of Yorkton passed on the 2nd day of September 1920, 3 September 1920, City of Yorkton Archives, Yorkton, Saskatchewan.
} 
business such Harry Bronfman, of whisky fame, who contributed \$2,000 to the fund (Figure 30), which was opened in 1930. Still 1929 was the start of tough times and not all memorial requests would be realized; Yorkton never did get its statue of an infantryman likely because as city archivist Therese Lefebvre Prince explained to me, they likely ran out of money because it was the beginning of the Depression. Yet, what was achieved was impressive in terms of remembrance through naming buildings, parks and the setting of memorials that would forever grace the prairie cities. What was not anticipated, in all cases, was the disrespect the memorials would have to endure through wanton vandalism that would come through the years.
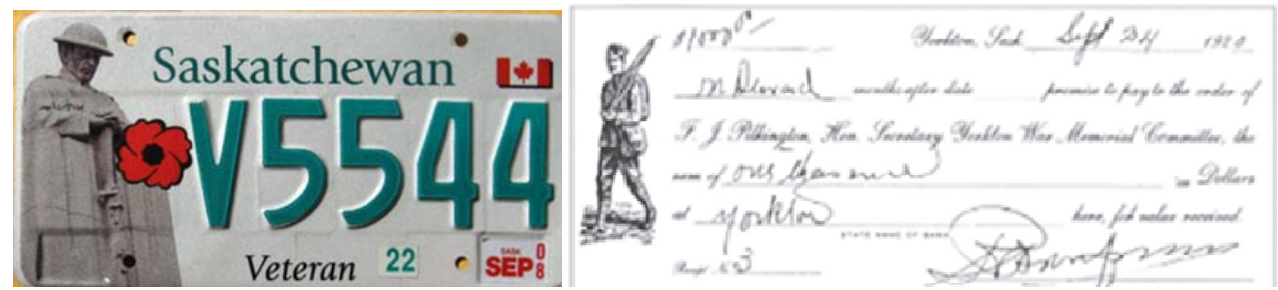

Figures 29-30. Veterans license plate with detail of Regina Victoria Park cenotaph; Bronfman promissory note, City of Yorkton Archives, Yorkton, Saskatchewan.

This August the news came from Regina of a second vandalism attack this year on the city's noble cenotaph. The monument was disgraced with spray painting at the base and the Leader-Post post included a photo (Figure 33) of cleaning services men at work scrubbing off the graffiti. Reporter D. C. Fraser identified the significance of the cenotaph and the public's outrage:

Premier James Gardiner said in his remarks at the unveiling in 1926 that the cenotaph was a "mark of respect to the dead and a challenge to the living" and that future generations should "realize the spirit which our men embodied in themselves when they went to the other side."

“My first thought was, 'Why would you do that?' said Owen Beck, who was sipping a coffee on a bench near the memorial Wednesday morning.

Amy Petrovitch said she saw the graffiti—-the word 'penis' in black writing on the east side of the cenotaph—on Tuesday as she was walking home from work around 5:15 p.m.

I was pretty shocked when I saw it. I mean, it's the cenotaph. It's the war memorial obviously—and can't believe someone had done something like that.",28

At Prince Albert a reporter interviewed the city’s manager when their memorial was vandalized:

Sometime last week someone spray painted the words "fack sakes" on the back wall of the memorial. City manager Jim Toye said they were told about it on Friday. He said the city's community services department is responsible for cleaning it up.

"I do know that when they were notified, they did make an attempt to remove the two words that are on the wall, with very little success,” said Toye.

He added that once spring hits they'll attempt to use sandblasting to remove the graffiti.

Toye said the City is disgusted by this vandalism.

"When you have cenotaphs [that] recognize people who are very important not only to the City of Prince Albert but to Saskatchewan and Canada, we don't like to see things like that," said Toye. "It is somewhat appalling that someone would think it's appropriate to vandalize something like that."29

${ }^{28}$ D. C. Fraser, "Reginians shocked by vandalism at cenotaph”, Regina Leader-Post, 25 August 2015.

29 Nigel Maxwell, “War memorial at City Hall vandalized”, paNow, 9 March 2015. 
In July 2008 Moose Jaw City Parks and Recreation director Jody Hauta lamented vandalism in Crescent Park, which included graffiti and destruction of light bulbs and power outlets. ${ }^{30}$. While these problems could be solved by the city, any restoration work, such as fixing the bent sword tip (Figure 32), would have to be taken on by local Legion Branch 59. ${ }^{31}$ One of the worst cases of vandalism occurred sometime after the 1927 unveiling of the Assiniboia cenotaph, which had its cenotaph standing soldier damaged so badly that it had to be removed from the front of the memorial. Fortunately, at Weyburn their exquisite statue was placed high up on a pedestal to avoid close contact and breakage. However, someone crawled up to the soldier to paint his face as the "Joker" (Figure 31) causing indignation on the part of citizens who viewed the vandalism firsthand and in the local newspaper. ${ }^{32}$ In all of these cases, it is helpful that newspapers continue to report on the vandalism of war memorials because it brings to light the disrespect individuals bring to the community when they deface public monuments and reinforces the support the populace has for its war dead.
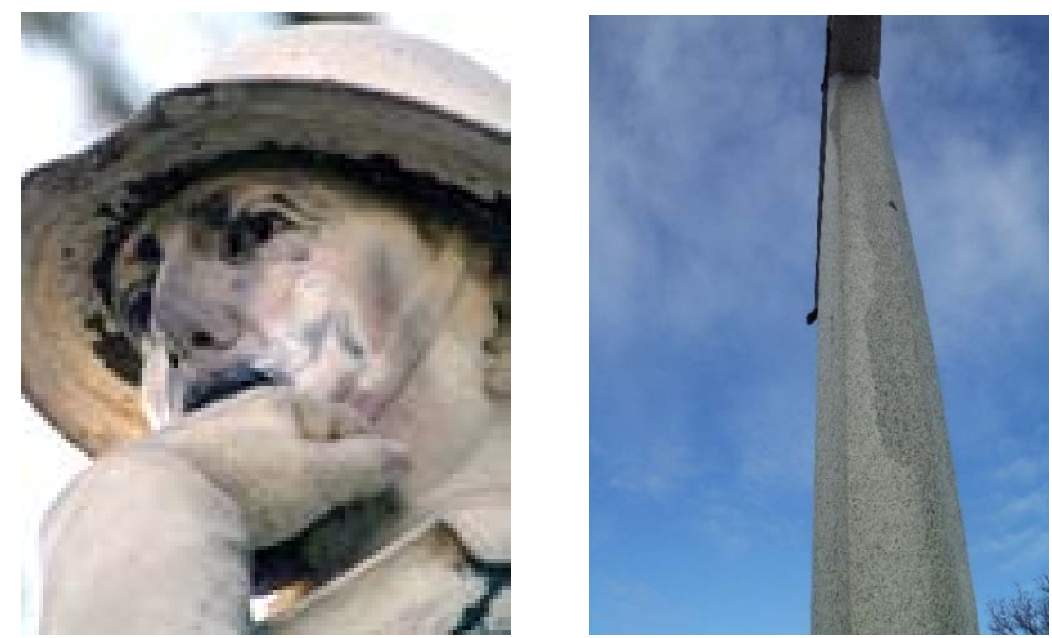

Figures 31-32. Weyburn cenotaph vandalized to look like the "Joker" Greg Nikkel photo, Weyburn Review, 10 November 2010; bent sword tip from Moose Jaw cenotaph, author’s photo.

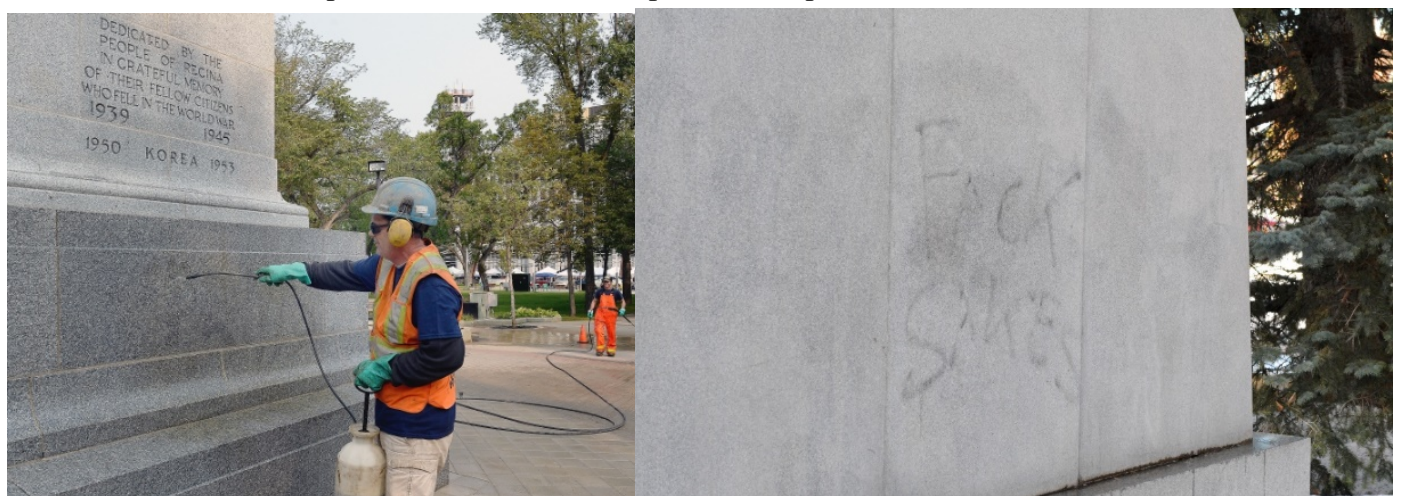

Figures 33-34. Vandalism at Victoria Park, Regina, 26 August 2015. Photograph by: Bryan Schlosser, Regina Leader-Post.; "Fake Sakes” vandalism on the Prince George cenotaph, Nigel Maxwell photo, PaNow Staff, 9 March 2015.

\footnotetext{
${ }^{30}$ Carter Haydu, “City doing what it can to curb cenotaph damage,” Moose Jaw Times-Herald, 15 July 2008.

31 In 2010, Veterans Affairs Canada announced the Cenotaph/Monument Restoration Program that offered up to \$25,000 for a restoration project. See Cenotaph/Monument Restoration Program, veterans.gc.ca (27 December 2015).

32 Greg Nikkel photo, “Cenotaph defaced”, Weyburn Review, 10 November 2010.
} 


\section{Remembering}

Recorded Legion history indicates that up to 1959, Armistice Day services in Moose Jaw were held in separate churches with a Veterans parade afterward to the Crescent Park cenotaph for the "wreath laying ceremony". There was common opinion that it would be better if services could be held together "under one roof" out of the cold. The solution came out of a meeting held the previous year earlier when some members from Legion Branch No. 59 attended a Dominion Convention in Edmonton where a replica of the Cross of Sacrifice was used as part of the indoor ceremonies. The Moose Jaw representatives (G. C. Moston \& R. W. Dillon) took the idea back to their city and in 1959 and obtained the plans of the Crescent Park cross from City Hall. Carpenters were then asked to build a scaled down model in wood sections to facilitate ease of moving. ${ }^{33}$ The replica was used for indoor ceremonies and became a part of the Civic Centre (hockey rink) indoor ceremonies for many years until recently moved to the new arena Mosaic Place at River Street and First Avenue. It was here that I returned to my memories of the cenotaph when I attended this years' Remembrance Day ceremony.

By 10:30 am on 11 November 2015 Mosaic Place, Moose Jaw, was nearing capacity $(4,500)$ for the annual Remembrance Day service. The life-size temporary cenotaph was set up between the boards of the hockey rink. An announcement informed the largely seated audience that the program would begin in ten minutes. This was the 97th annual Remembrance Day service and the turn out showed that the mission of remembering of the overseas fallen had remained alive in the community. After the colour guard entered their position and dignitaries and guests took their seats, the singing of "O Canada" unified those in attendance in warmth of familiarity. A hymn set the tone of remembrance and a homily on the cost of war touched deeper the sense of occasion. And then...the two minutes of silence marked the 11 o'clock hour. Time to be quiet, time to reflect on those who made the sacrifice of war.

For this brief moment one is able to touch another time and enjoy a coming to terms with thoughts of what 11 November means and from this some sense of completion on what happened to those citizens of the community so many years ago. Looking at the replica of the Crescent Park cenotaph I was able to complete the understanding that I missed as a youth when I hurried by the monument. Next, the "laying of the wreaths" filled the base of the wooden cenotaph with the colour of the poppy enhancing the "design of great simplicity".
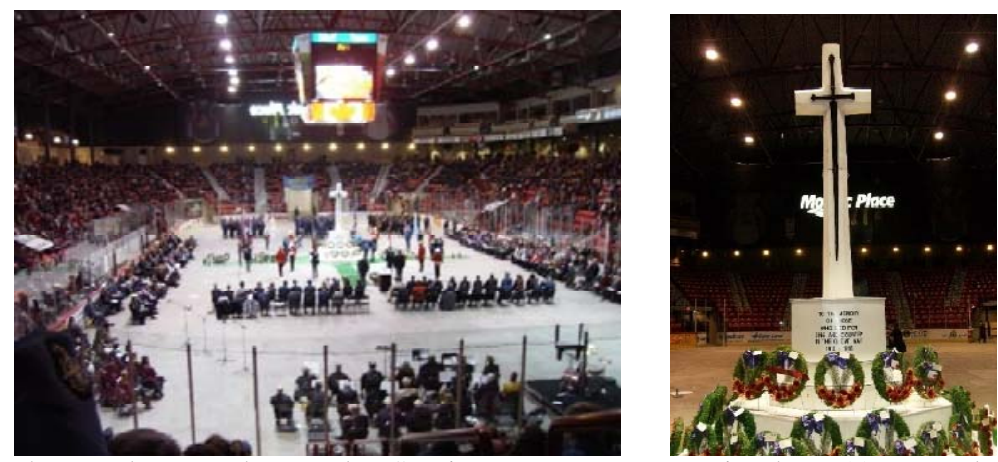

Figures 35-36. 97th annual Remembrance day Service, Moose Jaw Mosaic Place, 11 November 2015; Replica Cross of Sacrifice after laying the wreaths, author's photos.

33 The Royal Canadian Legion: Golden Years 1926-1976, Saskatchewan Branch No. 59 (Moose Jaw: Legion Branch No. 59, 1976), p. 36. 


\section{Conclusion}

The city cenotaph became a landmark - a place of identity in the prairie city. As the communities grew their marker of those who did not come back from the war would be honored by their city with annual remembrance ceremonies. The cenotaph offered a link with the past so that those of us who sit on the park bench today might recall a troubled time and how our citizens responded to the event of their lives. The mission for those of us who come after would be to protect these monuments of our heritage while we enjoy an attractive feature of the community that was devoid of sculpture before the cenotaph was erected.

\section{References}

About the commonwealth war graves commission cemeteries and memorials. cwgc.org. (29 December 2015).

Anglo-Boer war memorial project. www.casus-belli.co.uk/abwmp. (15 December 2015).

Argan, W. (2002). Regina: The first hundred years. Regina: The Leader-Post Carrier Foundation Inc.

Art.IWM ART 16377 1. Study for cenotaph, label comments, Imperial War Museum, London. iwm.org.uk.

Biblehub.com. Isiah 2:4, Ecclesiastics 44:9. (20 December 2015).

Cenotaph/monument restoration program. veterans.gc.ca. (27 December 2015).

Ceremony at the cenotaph to be most imposing. (1920, 25 June). Moose Jaw Evening News, n.p.

Crane, D. (2013). Empires of the dead: How one man's vision lead to the creation of WWI's war graves. London: William Collins.

Disapprove of war pictures for school decoration. (1923, 17 March). Vancouver Sun, n.p.

Dunning tells the school trustees. (1923, 22 February). Moose Jaw Evening Times, n.p.

Fraser, D. C. (2015, 25 August). Reginians shocked by vandalism at cenotaph. Regina Leader Post, n.p.

Geurst, J. (2010). Cemeteries of the Great War by Edwin Lutyens. 010 Publishers.

Golden Furrows: An historical chronicle of Swift Current. (1954). Swift Current: Local Council of Women.

Hanson, N. (2005). The unknown soldier: The story of the missing of the great war. Toronto: Doubleday.

Haydu, C. (2008, 15 July). City doing what it can to curb cenotaph damage. Moose Jaw Times-Herald.

Knight, L. (2009, 16 August). Council fretted over cenotaph site. Moose Jaw Times-Herald.

Lefebvre Prince, T. (2010, 19 May). History Corner. Yorkton This Week.

Maxwell, N. (2015, 9 March). War memorial at city hall vandalized. PaNow.

National inventory of Canadian military memorials. veterans.gc.ca. (15 December 2015).

Nikkel, G. (2010, 10 November). Photo, “cenotaph defaced”. Weyburn Review, n.p.

The royal Canadian legion: Golden years 1926-1976. (1976). Moose Jaw: Legion Branch No. 59.

Rye, Sussex: Home of the Menin Gate designer. (2014, 30 July). BBC.co.uk. (20 December 2015).

Saskatchewan Archives Board. scrapbook album R-1392, p. 55.

Sheftall, M. (2009). Altered memories of the Great War: Divergent narratives of Britain, Australia, New Zealand and Canada.

London: I. B. Tauris \& Co.

Trustees view fine pictures on exhibition. (1923, 20 February). Moose Jaw Evening Times, n.p.

Veterans Cemetery, God's acre-the cross of sacrifice. veterans.gc.ca. (20 December 2015).

Ware, F. (1924). Building and decorating of the war cemeteries. Journal of the Royal Society of Arts, 347.

War pictures not horrible: Very common. (1926, 9 October). Calgary Albertan, n.p.

Memorial cross is almost ready. (1921, 15 December). Moose Jaw Evening Times, n.p.

Wikipedia. Development of the war cemetery ideal. (29 December 2015).

Yorkton War Memorials Committee. (1920, 3 September). City of Yorkton Archives, Yorkton, Saskatchewan. 